\title{
MNE SPECIFIC FACTORS OF CORPORATE CAPITAL STRUCTURE: COMPARATIVE ANALYSIS IN TERMS OF FINANCIAL RESOURCES DEMAND AND SUPPLY
}

\author{
Sergiy TSYGANOV', Olga ZALISKO², \\ Institute of International Relations of Kyiv National Taras Shevchenko University, Ukraine
}

\begin{abstract}
This paper investigates corporate capital structure of multinational enterprises. Its core subject is focused on corporate capital structure defining factors that are specific for MNE rather than for domestic corporations. Substantial part of scientific literature concentrates on country specific and firm specific factors of corporate capital structure with most research devoted to domestic corporations. The main goal of our paper is to discover among plenty of corporate capital structure factors those that are specific for MNE and to develop a new approach for analyzing these factors in terms of financial resources demand and supply. There are some corporate capital structure factors that influence directly and some that have indirect influence while there is also another set of factors having both direct and indirect influence on indebtedness. Different theoretical and empirical research confirm different directions. Methodology of our study is based on analysis of two fundamental market driving forces that are demand and supply. Their influence on corporate capital structure is of a primary origin and that is why the suggested approach is to our mind theoretically significant and practically important. Demand factors imply that a corporation creates demand for financial resources and its capital structure is defined internally. Supply factors imply an external capital structure since it is created by external investors' supply of financial resources. On empirical level, we use the primary data of corporate financial statements to analyze the leverage of MNE based in different countries and representing different industries. The key results of our study show that the main MNE specific factors of capital structure include such demand factors as multinationality level, assets tangibility and political risk. The first two are firm specific factors that can influence corporate capital structure either directly or indirectly according to different theories and empirical studies. Political risk is a country specific factor which affects MNE indebtedness level directly. Exchange rate risk is another factor of MNE capital structure substantial influence. It can be either demand or supply factor that brings mostly to indirect influence on corporate indebtedness level. These factors obviously affect domestic corporations capital structure as well but to a much lesser extent. We also consider a set of behavioral factors to be essential for MNEs though they also affect domestic corporations.
\end{abstract}

Key words: MNE capital structure, country specific factors of capital structure, firm specific factors of capital structure, demand factors of capital structure, supply factors of capital structure.

JEL Classification: F21, F23, G32

\section{Introduction}

Capital structure of multinational corporations is nowadays affected by a number of different factors. Most of them underlie existing theories of corporate capital structure and have been deeply explored in contemporary scientific literature. Other factors do not actually have such a fundamental magnitude and are only the object of separate empirical tests. Moreover, some empirical tests suggest individual factors that are unique for only certain MNEs under certain conditions and cannot be applied all others not equal. The most common approach to investigate capital structure influencing factors is to distinguish between firm specific and country specific factors. Firm specific factors influence the capital structure on the level of a corporation and are internal in this sense. They are often of microeconomic origin. Country specific factors appear on a country level and are independent on a corporation itself. In these terms, they are regarded as external factors. Many of them are actually traditional macroeconomic factors.

However, another significant issue underlies the research of MNE capital structure. Depending on the nature of their influence, all capital structure factors can be divided

\footnotetext{
Corresponding author:

${ }^{1}$ Department of International Finance, Institute of International Relations of Kyiv National Taras Shevchenko University. E-mail: s_tsyganov@ukr.net

${ }^{2}$ Department of International Finance, Institute of International Relations of Kyiv National Taras Shevchenko University. E-mail: olga.zalisko@gmail.com
} 
into two groups: demand and supply factors and this issue is paid little attention to in the literature nowadays. The core goal of the present paper is to investigate main factors of corporate capital structure specific for MNE rather than to domestic corporations in terms of funding demand and supply. This problem is of a crucial importance considering two main issues. First, any market force driven with demand or supply is of a different nature. The order, direction and what is even more important the pattern of their influence on MNE capital structure differ significantly. Second, demand and supply nature of MNE capital structure formation will help better understanding the problem core idea and its main crucial points. This criterion is actually the primary one in view of main macroand microeconomic theories. Moreover, we aim to mark out MNE specific factors and to stress on international specifics of capital structure formation.

Considering the above mentioned the pointed problem appears to be scientifically significant and practically important. Its relevancy also corresponds with current processes and trends in a global economy where MNEs have become the key actors and their transactions can hardly be overestimated in terms of their volumes and influence on business and finance. MNE move huge financial resources between their affiliates located in many countries throughout the world thus making their network global, on the one hand. On the other hand, all these transactions are internal from corporate point of view and this is what makes global markets of such funding internal for MNEs dithering geographic borders.

\section{Literature review}

The MNE capital structure problem has been widely explored in contemporary scientific literature. All in all this great pile of scientific works can be divided into two main parts. The first one deals with the problems of corporate financial leverage in the sense of an economic effect produced by debt financing on corporate financial efficiency. This group of scientific research is represented with a number of traditional theories of corporate capital structure, particularly the dominating Miller-Modigliani paradigm (Modigliani and Miller, 1958). This theory states that a corporation market value is higher when it uses debt and equity than when it uses only shareholders capital. This is due to a tax shield which implies that a firm can cut its tax expenses by using debt financing in its capital structure. This is because interest can be deducted and excluded from corporate taxable income. Traditional approach to corporate capital structure considers the influence of capital structure on corporate weighted average cost of capital (WACC) and its market value. It primarily states that optimal WACC can be reached at the expense of maximizing debt financing level until certain point after which WACC will increase (Weston, 1963; Solomon, 1963).

The mentioned theories imply static capital structure that does not change but instead affects other corporate ratios, market and financial efficiency as a whole. However, the second group of theories implies dynamic capital structure that is influenced with specific factors. This is what actually our paper deals with. In mainstream of dominating paradigm, this group is uppermost represented by the third part of Modigliani \& Miller theory that along with corporate income taxes considers personal taxes as well. This Miller theory affirms that the average level of taxation is lower for dividend income than for interest profit and that is why investors prefer investing in stocks rather than in bonds (Miller, 1977). This motivation moves corporate capital structure towards equity capital. The pecking order theory affirms that a corporation should attract financial resources in compliance with certain hierarchy: internal funds or reinvestments, debt capital and then new equity (Myers and Majluf, 1984). It considers new equities to be issued when they are overvalued in the market. This will facilitate attracting more financing. Agency theory implies that managers do not always act for benefit of shareholders and creditors (Jensen and Meckling, 1976). The activity of top managers should be controlled that is associated with extra costs and agency expenses that are finally bared by shareholders. This point explains why corporate capital structure is gravitated towards equity rather than debt. The theory of asymmetric information of signaling theory assumes that corporate managers have insider information and use it (Ross, 1977). All others equal positive prospects of corporation development are attributed to new debt issue because managers do not want to share future profits with the large number of shareholders. Market perceives this as a signal and responds with increasing the stocks prices. Thus, the capital structure is likely to be in favor of equity capital to ensure certain standby for additional debt issue.

There is one of traditional theories that reconciles static and dynamic issues of corporate capital structure. This is a trade-off theory which states that capital structure is influenced with bankruptcy costs as well as by tax shield considerations in the opposite way (Kraus and Litzenberger, 1973). Thus, the trade-off between them should be found and that would be an optimal capital structure.

The mentioned theories have actually provided a rather deep insight into factors influencing corporate capital structure though there is a large portion of factors not covered and explored mostly in the framework of empirical research. As to the latest research, (Mokhova and Zinecker, 2014) explored macroeconomic factors of corporate capital structure that are actually related to the country specific group. Jõeveer, 2013 explored both firm specific and country specific factors of capital structure for corporation in transition economies.

One interesting point about empirical studies results is that they often give different and sometimes opposite conclusions. For instance, explaining capital structure from the point of view of different approaches particularly trade-off, agency and pecking order theories produce quite different interpretations. Thus, these 
approaches appear to be contradictory in many cases but are still theoretically significant and meaningful. Eventually one can point out many influencing factors with some of them being specific for only certain MNE under certain conditions. In our study we attempt to explore most typical factors affecting corporate capital structure especially for the case of MNEs and those ones mostly covered by the scientific literature. The distinctive point of our approach is that we investigate these factors in terms of demand for funding produced by MNEs and financial resources supply produced by investors. To the best of our knowledge, this criterion is seldom used in contemporary literature and if so only individual factors are considered and no general insight is presented. We also aim to stress on MNE specific factors among others typical for domestic corporations as well.

\section{Country specific factors}

Political risk is a factor that substantially affects not only MNE and affiliates capital structure but also corporate efficiency in general. It is mostly associated with relatively less developed economies. This risk can appear in unstable countries where governments can restrict repatriation, dividends transfer, block funds etc. Political risk can be of a micro and macro origin. Macropolitical risk concerns all corporations on the territory of foreign country irrespective of their activity. It implies possible expropriation of ownership in host country and the appearance of different ethnic, religious, racial and other conflicts. Micropolitical risk applies to certain industries, activities, corporations and even individual projects.

Micro type of political risk is predominantly typical for MNEs and it mostly arises as a result of corruption and mismatching of MNE and local governments goals. In terms of capital structure, political risk basically brings about the increase in affiliates indebtedness level while external debt accounting for major part of it (Desai et al., 2004). This is because the increase in political uncertainty contains such risks as restriction on repatriation and interest transfer, different exchange restrictions etc. MNE naturally respond with restricting internal transfers abroad in order to minimize such risks. More detailed research of political risks influence on modern MNE capital structure confirm that such influence should be regarded in terms of different forms of political risk realization. It can be realized for instance in strict administrative forms like government direct interference into repatriation issues or softer ones that could not even be introduced in more stable and developed business environment (Kesternich and Schnitzer, 2010, p. 208). It has been empirically proved that increase in political risk brings about the increase in MNE equity capital share (Kesternich and Schnitzer, 2010). This is because such restrictions result in investment projects returns cut while the level of expenses remains the same. As to the debt capital, the case is rather ambiguous. Optimal level of debt financing decreases with increase of political risk in the form of complete or gradual expropriation since the last brings about higher bankruptcy risks.

Development level and conditions on local capital markets is also an important factor of MNE capital structure. It is well known that MNE affiliates use less external debt funding and more internal in countries with low level of capital markets development and where the level of creditors rights protection is weak. This is because attracting financing on such markets is rather expensive (Desai et al., 2004). It means that internal financing can replace more expensive external. As a result, MNE would have competitive advantages over local corporations that can attract funding on domestic markets only. The level of creditors' rights protection directly affects financial markets development uppermost the markets of debt. There are two opposite views of this matter (Cho at al., 2014). The first one focuses on resources market supply and affirms that high level of creditors' rights protection positively influences the use of debt fund by corporations. This point is explained by the fact that the proper level of protection allows creditors to lend on better terms because they are confident to get their loans back and corporations in turn get more debt funding in their capital structure. The second view emphasizes market demand and affirms that the proper creditors' rights protection level negatively affects corporate indebtedness level. Illustration of this point appears as follows. In case of financial distress equity holders (uppermost) and other creditors don't want to lose control over a corporation. Different countries treat creditors, stockholder and managers in different ways. In the USA, that is considered to have the poor creditor rights protection level, for example, managers rather than creditors are considered to have the prior right to elaborate and implement corporate anti-crisis strategy (Cho at al., 2014). In countries with high level of creditors' rights protection managers can be dismissed during financial distress and replaced by creditors. Interested managers thus are to be interested to use less debt capital.

Though contemporary scientific literature contains empirical verification for both views, it mostly confirms the idea that high level of creditors' rights protection facilitates the decrease in long-term debt share, for example (Cho at al., 2014). The authors explored 151,855 corporations from 48 countries and their capital structure under influence of a special index of creditors' rights protection in the period between 1991 and 2010. Capital structure was explored via long-term debt ratio that was calculated as a relation of long-term debt to total assets. Creditors' rights protection index is an index elaborated by Djankov et al., 2007. It can reach values of $0,1,2,3$ and 4 , where 0 is the lowest level of creditors' rights protection or its actual absence and 4 is the highest level. Besides the main conclusion mentioned above we should consider three following important quantitative results of this study. First, the sample average long-term debt ratio is 0.58 though it does not exceed the level of 0.23 if considering any of 48 countries. Second, this maximum value of 0.58 corresponds to respective 
maximum value of Djankov index that is 4 . Third, the sample average ratio is 0.12 with an index value of 2 .

Besides creditors' rights protection conditions on local capital markets are also defined by such legal factors as investors' rights protection, corporate information disclosure requirements, burden of proof, public enforcement etc. The overall idea of these factors influence implies that they speed up the information dissemination, decrease agency costs and bankruptcy costs (Mishra and Tannous, 2010). Under these conditions, creditors tend to lend more and require lesser returns. This in turn brings about that corporations increase the level of debt financing.

Among country specific factors contemporary scientific literature points out the level of bankruptcy code and respective legal rules and regulations development as well as individual technical factors such as audit standards etc. (Antonczyk and Salzman, 2014). In countries with powerful and detailed bankruptcy codes corporations tend to have higher shares of debt funds in their capital structure, since creditors' rights are considered to be strongly protected and they tend to lend at more favorable terms (Giannetti, 2003). Though this factor is closely connected with the previously mentioned one, it theoretically implies narrower sense. More progressive accounting and audit standards can influence the level of informational asymmetry and soften agency conflicts (Antonczyk and Salzman, 2014). Thus, the capital structure can be explained in terms of agency theory and it tends towards debt all others equal.

A country legal system in general is also regarded as corporate capital structure factor. In this sense one should distinguish between civil law and common law that are basically two main sources of law nowadays. Countries with dominating common law suggest investors a better protection compared to the countries where civil law dominates (La Porta et al., 1998). It means that in common law countries corporate capital structure tends to have more equity than debt.

As to these factors they obviously influence not only MNE but domestic corporations as well. Notwithstanding, we consider them to be of crucial importance for MNE by two main reasons. First, domestic corporations have some conditions as given. They have what they have in their domestic economy and that is often a constant. These conditions are sort of external variable for local corporations that cannon be changed. MNE can vary between countries and choose among all possible sets of conditions and domestic constants. This can be regarded as an internal variable for MNEs since they can change them by either investing or not or by using special internal fund repositioning instruments and international debt shifting strategy. Second, MNEs have much more opportunities to avoid some possible domestic restrictions or to decrease their negative influence. In these terms the mentioned factors are quite suitable for MNE to deal with. All in all there can be a lot of country specific factors affecting corporate capital structure. The matter is which of them can be rationally grounded and explained and what is more important in the course of our study which of them are more influential for MNE rather than for domestic corporations. We tried to cover those factors, which have been explored in scientific literature and are typical for MNE.

\section{Firm specific factors}

An interesting research subject would be to compare capital structure of domestic and multinational corporations. Such test has hardly been carried out in the full statistical understanding of this issue. We mean three core points here. First, the availability of data for a maximum number of countries and for MNE as well as for domestic corporations. Second, the availability of data for all possible industries. Third, the availability of methodologically comparable data, which can be presented either in one standard or another. These points bring about that the study of this type contains mostly some of the above-mentioned limitations. We do not pretend to

Table 1

Long-term debt ratio of MNEs from different home countries

\begin{tabular}{|c|c|c|c|}
\hline Year & $\begin{array}{c}\text { Toyota Motor } \\
\text { Corporation }\end{array}$ & Nestlé SA & $\begin{array}{c}\text { Wal-Mart } \\
\text { Stores Inc. }\end{array}$ \\
\hline 2004 & 0.1927 & 0.0806 & 0.1907 \\
\hline 2005 & 0.2061 & 0.0672 & 0.1936 \\
\hline 2006 & 0.1963 & 0.0683 & 0.2178 \\
\hline 2007 & 0.1923 & 0.0531 & 0.2028 \\
\hline 2008 & 0.1843 & 0.0597 & 0.2043 \\
\hline 2009 & 0.2168 & 0.0808 & 0.2114 \\
\hline 2010 & 0.2312 & 0.0670 & 0.2136 \\
\hline 2011 & 0.2156 & 0.0544 & 0.2425 \\
\hline 2012 & 0.1971 & 0.0664 & 0.2434 \\
\hline 2013 & 0.2068 & 0.0860 & 0.2039 \\
\hline 2014 & 0.2063 & 0.0929 & 0.2176 \\
\hline 2015 & & & 0.2145 \\
\hline Average & 0.2041 & 0.0706 & 0.2130 \\
\hline Domestic & & & \\
\hline Average & 0.11 & 0.15 & 0.15 \\
\hline
\end{tabular}

Notes:

1. Calculated by the authors using corporate consolidated financial statements for respective years.

2 . The ratio is methodologically computed as a relation of long-term debt to total assets.

3. Reporting financial years end on different dates in different countries: the USA (Wal-Mart Stores Inc.) - December 31, Switzerland (Nestlé SA) - December 31, Japan (Toyota Motor Corporation) - March 31.

4. 'Average' is computed as a simple arithmetic average.

5. 'Domestic average' is a figure presented in (Cho et al., 2014) and is an average long-term debt ratio for domestic corporations in Japan, Switzerland and the USA respectively.

\footnotetext{
${ }^{1}$ These three MNEs have been selected from UNCTAD top-100 non-financial TNCs rating considering different industries and different home countries being represented.
} 
fill this gap in the present study but just try to compare some typical MNEs from different home countries and representing different industries ${ }^{1}$ (table 1 ).

The above-mentioned issues of MNE activity on international markets allows assuming that they would have relatively more debt in their capital structure, particularly due to more favorable borrowing conditions on internal and international markets. However, the data of table 1 shows that 2 of 3 average ratios for MNE substantially exceed the average ratio of 0.12 for domestic corporations from the mentioned study. The equal 0.2041 and 0.2130 for Toyota Motor Corporation and Wal-Mart Stores Inc. respectively. Only the average ratio for Nestlé SA is smaller -0.0706 . What is important, average ratios for Toyota and Wal-Mart also substantially exceed average ratios for domestic corporations in these countries that equal 0.11 and 0.15 respectively. For Nestlé this figure is again more than twice lower, though this difference can be explained by industry specificity.

To support this contradiction we must mention that a traditional statement of such hypothesis stems from Dunning OLI paradigm. It implies that MNE have unique specific assets including technology, patents, brands and what is more important the ability to create such assets that allows them to successfully compete in international markets (Rogach, 2005). Such hypothesis statement allows to assume that MNE must have relatively low ratios of debt capital usage since the availability of specific assets affects the increase in returns and growth potential, high market-to-book equity ratios that is typical for low debt using companies (Park et al., 2013). Empirical results of this research show, that US multinationals and domestic corporations do not differ significantly in their capital structures.

Most studies however confirm the idea that MNE use relatively less debt in their capital structure than domestic corporations (Lee and Kwok, 1988). This is explained mostly using the agency theory according to which MNE have higher level of agency expenses and information asymmetry and thus tend to cut debt financing (Burgman, 1996). Agency costs also increase due to greater vulnerability of MNEs to local legal and political factors (Doukas and Pantzalis, 2003).

Another important for MNE firm specific factor of corporate capital structure is the tangibility of assets. Here the literature considers what type of assets - tangible or intangible - prevails in corporate asset set. According to the trade-off theory, intangible assets are more sensitive to corporate problems and this brings about the lower investor value during financial distress or bankruptcy (Hart and Moore, 1994). The idea of this message is that intangible assets have lower liquidation value. It means that corporations with more tangible assets can afford attracting more debt financing since tangible assets have higher liquidation value. In terms of agency theory, intangible assets are riskier and can be replaced by riskier assets. Thus, they can be lost or illegally expropriated with higher probability. Tangible assets are less risky and are more often used as a collateral thus decreasing creditor's agency risk. Therefore, corporations tend to increase the share of equities in their capital structure if they have relatively more intangible assets. The pecking order theory states that corporations with higher share of tangible assets are less exposed to information asymmetry compared to corporations with higher shares of intangible assets. It means that equity issue is cheaper for such corporations and thus the use of debt decreases.

The importance of this factor for MNE has two main explanations. First, the existence of intangible assets is one of the main features of MNE. It helps them compete on the global marketplace and provides them competitive advantages before domestic corporations. This point arises particularly from eclectic OLI paradigm. MNE actually use intangible assets much more intensively compared to domestic corporations. Second, besides having these specific intangible assets MNE have unique ability to create new assets of this type. They often create global internal markets for these assets where a unique system of pricing and circulation exists. More than 2/3 of global market of technologies is MNE internal market with technology being the direct product of MNE specific intangible assets.

\section{Firm and country specific factors}

Along with purely firm specific and purely country specific corporate capital structure factors, there is a small group of factors of dual character. They can be country specific as well as firm specific while being of a crucial importance for MNE in any case. These are an exchange rate risk and a behavioral factor.

Exchange rate risk is inherent for MNE to much higher extent than for domestic corporations. It is also closely connected with such macroeconomic factors as inflation and interest rates. If for example the currency of a country where an MNE affiliate is located depreciates an MNE will be interested not to extract cash flows from this economy in more stable currency. It means that debt financing is to be redistributed in favor of external (in terms of corporate internal financial system) resources. Such funding can be attracted on local market of a host country. In this case, exchange rate risk would be absent. It is however rather difficult to estimate whether this will bring about the redistribution between equity and debt in corporate capital structure. To our mind, it will rather result in cut of debt financing, especially in countries with relatively weak currencies. The reason is as follows. Internal funding from a parent generates a certain affiliate capital structure. The currency weakness brings about that the loans repay substantially changes the affiliate's future cash flows. It must repay much more that it received in local currency what considerably increases risks. The increased future cash flows will as a result bring about the reverse influence on capital structure to much higher extent than they did when the loan was received. It means that a corporation must introduce additional measures to restore the capital 
structure back. Financing in the form of FDI looks more attractive in this case.

Exchange rate risk can be either firm or country specific factor as has already been mentioned. If we consider the host country with weak currency in general, the exchange rate risk will concern all affiliates of foreign MNE having assets in more stable currencies. If for example an affiliate in a country with strong currency attracts capital issuing papers in weak currencies the exchange rate risk will actually be such for this affiliate only. Other companies in this country will not face this type of risk. To decrease or eliminate exchange rate risk influence on capital structure MNE often use a so-called international debt shifting strategy.

Another factor that can be either firm specific or country specific is a behavioral factor. It should actually be regarded as a group of factors rather than as a single one. If considering for example gender and age structure of corporate management bodies behavioral factors which appear to be firm specific ones since decisions are taken at corporate level influenced by behavioral features of certain individuals. Women tend to borrow less than men that is explained not only by their attitude towards future returning of borrowed money but also by their more emotional perception of loans as such. Thus MNE where women prevail in management bodies tend to have more equity and less debt in their capital structure. Age of corporate top management, according to behavioral theories, negatively affects debt financing. Thus, corporations where young men dominate in management bodies usually use relatively less equity and more debt in capital structure.

Being a country specific factor, behaviorism considers corporate capital structure in terms of country's cultural, religious, social, mental and other features. The general behavioral idea is that unlike traditional assumptions about individuals rational behavior aimed at utility maximization in real life people do not often follow such behavioral pattern since they can be optimistic and overconfident (Malmendier et al., 2011). It means that individuals consider the probability of favorable events higher than it really is and they are sure that they know about these events more than they really do. Thus, real life financial decisions of individuals particularly regarding the corporate capital structure are substantially defined by mentioned irrational issues.

Most scientists agree that such behavioral features as overconfidence and optimism positively influence the indebtedness level for two basic reasons. First, managers that overestimate their company profitability consider its stocks to be substantially undervalued and thus prefer debt financing. Second, overconfident managers consider their corporation cash flows to be less volatile than they really are and therefore underestimate the probability of financial distress and bankruptcy.

According to this approach, countries are considered in terms of their individualism level that is a factor of corporate capital structure (Antonczyk and Salzman, 2014). Individualism is something that defines the level of overconfidence and optimism of individuals, particularly corporation managers. The main conclusion of the mentioned research is that corporate managers in countries with high individualism level show overconfidence and optimism that brings about more substantial shares of debt in corporate capital structure. To our mind, the mentioned cultural and behavioral peculiarities are specific for MNE. Multinationals operate in cross-cultural environment and their managers and even workers represent different nationalities, cultures and religions.

Religion is among important behavioral factors of MNE capital structure. Catholics and Protestants for example differently perceive indebtedness as such. Some research show that in Catholicism dominating countries corporations have higher shares of debt in their capital structure than corporations in Protestantism dominating countries do (Baxamusa and Jala, 2014). It is also well known that Islamic religion and the Sharia have extremely negative attitude towards lending as such (to much lesser extent to borrowing). That is why in Islamic countries corporations tend to have capital structures with much lower shares of debt. For cross-cultural environment of MNE operations this conclusion should be used in terms of corporate management religious structure analysis especially on the level of strategic decisions taking.

\section{Demand and Supply Approach}

We have considered the two widespread criteria of corporate capital structure classification that imply the distinguishing between country specific and firm specific factors and between economic and non-economic factors. However, to our mind one more important criterion allows to classify them into demand and supply factors. The core idea underlying is the origin of a factor influence. Some factors can be driven by either demand or supply and they have a double origin. In these terms by demand we mean the demand for funding from MNEs and by supply we understand the supply of financial resources, that is created by investors ready to buy corporate securities or to lend them money. The importance of this criterion can be grounded by two principal reasons. First, from economic point of view the motivation arising under demand influence and under supply impact differ significantly. In a demand driven case the capital structure is defined by financial decisions of a corporation itself, since it creates the demand for financial resources. Demand is in fact a result of one or another policy of corporate capital structure that is in turn a sort of endogenous issue from corporate point of view. A supply driven motivation is exogenous from corporate point of view. Corporate capital structure policy is in this case a response to changes in certain external conditions - resources supply. Second, demand factors substantially exceed supply ones in terms of their quantity as well as in terms of their magnitude. The matter is that demand as such is a result of corporate decisions and 
affects capital structure much intensively. Major capital structure theories have demand factors underlying. The explored factors are arranged according to the demand or supply character of their influence and classified according to the possible direction of their impact (table 2).

Table 2

Factors of MNE capital structure (use of debt funds)

\begin{tabular}{|l|c|c|c|}
\hline \multicolumn{1}{|c|}{ Factor } & \multicolumn{2}{c|}{ Influence Direction } \\
\cline { 2 - 4 } & Direct & Indirect & $\begin{array}{c}\text { Direct and } \\
\text { Indirect }\end{array}$ \\
\hline FIRM SPECIFIC FACTORS & & & \\
\hline Assets tangibility & & & $\mathrm{D}$ \\
\hline $\begin{array}{l}\text { Internationalization and } \\
\text { multinationality }\end{array}$ & & & $\mathrm{D}$ \\
\hline $\begin{array}{l}\text { COUNTRY CPECIFIC } \\
\text { FACTORS }\end{array}$ & & & \\
\hline Bankruptcy code development & $\mathrm{D} / \mathrm{S}$ & & \\
\hline Source of law - civil & $\mathrm{D} / \mathrm{S}$ & & \\
\hline Source of law - common & & $\mathrm{D} / \mathrm{S}$ & \\
\hline Audit and accounting standards & $\mathrm{D}$ & & \\
\hline Creditors' rights protection & & & $\mathrm{D} / \mathrm{S}$ \\
\hline Disclosure requirements & $\mathrm{S}$ & & \\
\hline Legal system development & & & $\mathrm{D} / \mathrm{S}$ \\
\hline Political risk & $\mathrm{D}$ & & \\
\hline $\begin{array}{l}\text { Host country capital market } \\
\text { development }\end{array}$ & & & $\mathrm{D} / \mathrm{S}$ \\
\hline $\begin{array}{l}\text { COUNTRY AND FIRM } \\
\text { SPECIFIC FACTORS }\end{array}$ & & & \\
\hline Exchange rate risk & & $\mathrm{D} / \mathrm{S}$ & \\
\hline Behavioral factors: & & & \\
\hline Management gender - men & $\mathrm{D}$ & & \\
\hline Management gender - women & & $\mathrm{D}$ & \\
\hline Management age & & $\mathrm{D}$ & \\
\hline $\begin{array}{l}\text { Country individualism level } \\
\text { (overconfidence and optimism) }\end{array}$ & $\mathrm{D}$ & & \\
\hline Religious factor - Islam & & $\mathrm{S}$ & \\
\hline Religious factor - Catholicism & $\mathrm{S}$ & & \\
\hline Religious factor - Protestantism & & $\mathrm{S}$ & \\
\hline
\end{tabular}

\section{Notes:}

1. Elaborated and compiled by authors.

2. «Direct and indirect influence» means that different theories and / or empirical research different possible directions of impact are explored.

3. $\ll D \gg-$ demand factor. $\ll S \gg-$ supply factor. $\ll D / S »-$ a factor can be either a demand factor or a supply factor.

The table 2 data allows to state that the suggested classification criterion allows making the following important generalizations and conclusions. First, all firm specific factors are demand factors. They define the MNE capital structure by creating a demand for financial resources from corporations ${ }^{2}$. Second, country specific factors are mostly supply and demand factor. On the one hand, they affect corporate financial decisions and, on the other, they define the general situation in a country including macroeconomic conditions thus affecting the decisions of investors who invest in corporate securities. Third, there are factors that can affect corporate capital structure either on the level of a firm or on a country level. They are the exchange rate risk factor and a set of behavioral factors. Some of them are demand factors and others are supply factors while some can be demand and supply factors. Fourth, all country specific and firm specific factors influence the corporate capital structure of MNEs and their affiliates as well as of domestic corporations. However, some of them are especially important for MNE and to a lesser extent for domestic corporations. Some factors cannot influence the capital structure of domestic corporations at all. For example, firm specific factors in table 2 are typical for MNEs though there can be much more factors influencing the capital structure of domestic corporations as well. Among them are, for example, corporate income tax, profitability, liquidity and others. Fifth, firm specific factors have stricter influence and their effect can be clearly distinguished for MNEs and for domestic corporations. At the same time country specific factors produce much wider effect on corporate capital structure which is much more difficult to be divided into multinational and domestic subeffects. That is why there are much more country specific factors that can be typical for MNEs. Notwithstanding, there are factor affecting corporate capital structure purely for multinationals. They are exchange rate risk, level of multinationality, host country capital markets development level and political risk.

\section{Conclusions}

Factors of corporate capital structure can be either firm specific, country specific, firm and country specific. Different theories and empirical research explain the influence of different factors on corporate capital structure differently, that is why some factors can affect directly and / or indirectly. Some factors of corporate capital structure influence either MNEs or domestic corporations, but some of them are typical for MNE to a larger extent. They are the level of multinationality and internationalization and assets tangibility on the level of a firm. Among country specific factors MNE capital structure is substantially affected by political risks and the level of host country capital market development. Other country specific factors influence MNE as well as domestic corporations. Among factors of combined influence exchange rate risk is essential for MNEs, while a set of behavioral factors is also substantial for MNEs but also affects domestic corporations.

One important criteria underlies the pattern of different factors influence on capital structure. According to the origin of influence, they can be divided into demand and supply factors, while some of them can be demand and supply factors at the same time. Demand factors imply that a corporation creates demand for financial resources and its capital structure is defined internally. Supply factors imply an external capital structure since it is created by external

\footnotetext{
${ }^{2}$ By "all firm specific" we mean not only those factors covered in our study but all influencing factors. They are all demand factors.
} 
investors supply of financial resources. Firm specific factors have much stricter influence and their effect can be clearly distinguished for MNEs and for domestic corporations. Country specific factors produce much wider effect on corporate capital structure which is much more difficult to be divided into multinational and domestic sub-effects. That is why there are much more country specific factors that can be typical for MNEs. Notwithstanding, there are factors affecting corporate capital structure purely for multinationals. They are exchange rate risk, level of multinationality, political risk, assets tangibility and the level of host country capital market development. Behavioral factors also substantially affect MNE capital structure but also influence domestic corporations.

\section{References}

Antonczyk, R.C., Salzmann, A.J. (2014). Overconfidence and Optimism: The Effect of National Culture on Capital Structure. Research in International Business and Finance, Vol. 31, p. 132-151.

Baxamusa, M., Jala, A. (2014). Does Religion Affect Capital Structure? Research in International Business and Finance, Vol. 31, issue 1, p. 112-131.

Burgman, T.A. (1996). An Empirical Examination of Multinational Corporate Capital Structure. Journal of International Business Studies, Vol. 27, issue 3, p. 553-570.

Cho, S., Ghoul, S., Guedhami, O., Suh J. (2014). Creditor Rights and Capital Structure: Evidence from International Data. Journal of Corporate Finance, Vol. 25, p. 40-60.

Desai, M.A., Foley, C.F., Hines, J.R.,Jr. (2004). A Multinational Perspective on Capital Structure Choice and Internal Capital Markets. The Journal of Finance, Vol. 59, issue 6, p. 2451-2487.

Djankov, S., McLiesh, C., Shleifer, A. (2007). Private Credit in 129 Countries. Journal of Financial Economics, Vol. 84, issue 2, p. 299-329.

Doukas, J.A., Pantzalis, C. (2003). Geographic Diversification and Agency Costs of Debt of Multinational Firms. Journal of Corporate Finance, Vol. 9, issue 1, p. 59-92.

Giannetti, M. (2003). Do Better Institutions Mitigate Agency Problems? Evidence from Corporate Finance Choices. Journal of Financial and Quantitative Analysis, Vol. 38, issue 1, p. 185-212.

Hart, O., Moore, J. (1994). A Theory of Debt Based on the Inalienability of Human Capital. The Quarterly Journal of Economics, Vol. 109, issue 4, p. 841-879.

Jensen, M.C., Meckling W.H. (1976). Theory of the Firm: Managerial Behavior, Agency Costs and Ownership Structure. The Journal of Financial Economics, Vol. 3, issue 4, p. 305-360.

Jõeveer, K. (2013). Firm, Country and Macroeconomic Determinants of Capital Structure: Evidence from Transition Economies. Journal of Comparative Economics, Vol. 41, issue 1, p. 294-308.

Kesternich, I., Schnitzer, M. (2010). Who Is Afraid of Political Risk? Multinational Firms and Their Choice of Capital Structure. Journal of International Economics, Vol. 82, issue 2, p. 208-218.

Kraus, A., Litzenberger, R. (1973). A State-Preference Model of Optimal Financial Leverage. The Journal of Finance, Vol. 28, issue 4, p. 911-922.

La Porta, R., Lopez-de-Silanes, F., Shleifer A., Vishny R. (1998). Law and Finance. The Journal of Political Economy, Vol. 106, issue 6, p. 1113-1155.

Lee, K.C., Kwok, C.C. (1988). Multinational Corporations vs. Domestic Corporations: International Environmental Factors and Determinants of Capital Structure. Journal of International Business Studies, Vol. 19, issue 2, p. $195-217$. Malmendier, U., Tate, G., Yan, J. (2011). Overconfidence and Early-life Experiences: The Effect of Managerial Traits on Corporate Financial Policies. The Journal of Finance, Vol. 66, issue 5, p. 1687-1733.

Miller, M. (1977). Debt and Taxes. The Journal of Finance, Vol. 32, issue 2, p. 261-275.

Mishra, D., Tannous G. (2010). Securities Laws in the Host Countries and the Capital Structure of US Multinationals. International Review of Economics and Finance, Vol. 19, issue 3, p. 483-500.

Modigliani, F., Miller, M. (1958). The Cost of Capital, Corporation Finance and the Theory of Investment. The American Economic Review, Vol. 48, issue 2, p. 261-297.

Mokhova, N., Zinecker, M. (2014). Macroeconomic Factors and Corporate Capital Structure. Procedia - Social and Behavioral Sciences, Vol. 110, p. 530-540.

Myers, S.C., Majluf N.S. (1984). Corporate Financing and Investment Decisions when Firms Have Information that Investors Do Not Have. The Journal of Financial Economics, Vol. 13, issue 3, p. 187-221.

Park, S.H., Suh, J., Yeung, B. (2013). Do Multinational and Domestic Corporations Differ in Their Leverage Policies? Journal of Corporate Finance, Vol. 20, p. 115-139.

Rogach, O.I. (2005). Transnatsionalni korporatsii v svitoviy ekonomitsi : Monographiya. Kyiv : Vydavnychopoligraphichniy tsentr «Kyyivskiy universytet $\gg: 176$.

Ross, S.A. (1977). The Determination of Financial Structure: The Incentive-Signaling Approach. The Bell Journal of Economics, Vol. 8, issue 1, p. 23-40.

Solomon E. The Theory of Financial Management - New York, Columbia University Press, 170 p.

Weston, J.F. (1963). A Test of Cost of Capital Propositions. Southern Economic Journal, Vol. 30, issue 1, p. $105-112$. 


\section{Сергей ЦЫГАНОВ, Ольга ЗАЛИСКО}

\section{ФАКТОРЫ СТРУКТУРЫ КАПИТАЛА ТНК: СРАВНИТЕЛЬНЫЙ АНАЛИЗ В КОНТЕКСТЕ СПРОСА И ПРЕДЛОЖЕНИЯ ФИНАНСОВЫХ РЕСУРСОВ}

Аннотация. В данной статье рассматривается структура капитала транснациональных компаний. Основным предметом её внимания являются факторы структуры капитала, характерные именно для ТНК, а не для национальных корпораций. Значительная часть научной литературы посвящена анализу корпоративных и страновых факторов структуры капитала, причём большая часть работ посвящена национальным корпорациям. Основной челью нашей работы является выявление среди множества факторов корпоративной структуры капитала тех, которые являются характерными для ТНК, и формирование нового подхода к анализу этих факторов - на основании анализа спроса и предложения финансовых ресурсов. Среди факторов корпоративной структуры капитала некоторые осуществляют прямопропорциональное влияние на уровень использования заемных средств, а некоторые - обратнопропорциональное. Различные теоретические и эмпирические исследования подтверждают разные направления такого влияния. Методология нашего исследования базируется на анализе двух главных движущих сил рынка - спроса и предложения. Их влияние на корпоративную структуру капитала является первичным, и поэтому предложенный подход, на наш взгляд, является теоретически значимым и практически важным. Факторы спроса предполагают, что корпорация создаёт спрос на финансовые ресурсы, а структура её капитала формируется на внутреннем уровне. Факторы предложения рассматривают структуру капитала как внешнюю субстанцию, поскольку она формируется под влиянием предложения финансовых ресурсов со стороны внешних инвесторов. На эмпирическом уровне мы используем первичные данные финансовой отчётности ТНК, на основании которых анализируем уровень задолженности ТНК разных стран базирования и разных отраслей. Основные результаты нашего исследования свидетельствуют, что главными факторами структуры капитала ТНК, которые в гораздо меньшей степени характерны для национальных корпораций, являются такие факторы спроса, как уровень транснациональности, материальный характер активов и политические риски. Первые два являются факторами корпоративного уровня и могут осуществлять как прямое, так и непрямое влияние на структуру капитала. Политический риск является страновым фактором и прямопропорционально влияет на уровень использования заёмных средств. Валютный риск также существенно влияет на корпоративную структуру капитала. Он может быть как фактором спроса, так и фактором предложения, осуществляя преимущественно обратное влияние на уровень корпоративной задолженности. Эти факторы, очевидно, также влияют на структуру капитала национальных корпораций, однако в гораздо меньшей степени. Мы также рассматриваем комплекс поведенческих факторов таким, что существенно влияет на структуру капитала ТНК, хотя эти факторы оказывают влияние и на национальные корпорации. 